\title{
Peningkatan Antusiasme dan Pemahaman Siswa dalam PBM melalui Metode Talking Stick di MIM Jatisari Kedungdowo, Boyolali
}

\author{
Atiqa Sabardila ${ }^{1}$, Arif Rahman Fachri ${ }^{2}$, Eric Santoso ${ }^{3}$, \\ Ninik Nur Aini ${ }^{4}$, Mila Safitri ${ }^{5}$, Dita Meinindya Putri ${ }^{6}$, Novita Aisah Damayanti ${ }^{7}$, \\ Linda Hermawati ${ }^{8}$, Adisti Nur Pratiwi ${ }^{9}$, Ria Safira ${ }^{10}$ \\ ${ }_{1,2,3,4,5,6}$ Fakultas Keguruan dan Ilmu Pendidikan, Universitas Muhamamdiyah Surakarta, Indonesia
}

\section{INFORMASI ARTIKEL}

\section{Histori Artikel:}

Submit: 27 April 2020

Revisi: 2 Mei 2020

Diterima: 4 Mei 2020

Publikasi: 6 Mei 2020

Periode Terbit: Desember 2019

\section{Kata Kunci:}

proses belajar-mengajar,

talking stick,

pembelajaran interaktif

\section{Correspondent Author:}

Arif Rahman Fachri

Fakultas Keguruan dan Ilmu Pendidikan

Universitas Muhammadiyah Surakarta,

Indonesia

Email: ariffahri@gmail.com

\begin{abstract}
ABSTRAK
Proses belajar-mengajar merupakan suatu cara guru dan murid berinteraksi dengan menciptakan suasana kelas yang kondusif dan menarik minat belajar siswa. Untuk itu, guru sangat penting memilih metode pembelajaran supaya siswa semangat dan termotivasi untuk belajar di sekolah. Metode talking stick yang telah diterapkan di MIM Jatisari, Kedongdowo, Boyolali merupakan metode yang tepat dalam meningkatkan antusiasme dan pemahaman belajar siswa. Aplikasi metode ini telah menjadikan siswa dengan mudah memahami apa yang mereka pelajari, membuat siswa aktif di dalam kelas, mendapat kesempatan yang sama karena mendapat giliran memegang tongkat yang mengharuskan mereka menjawab pertanyaan guru, dan berpengalaman mengekspresikan pendapatnya di kelas. Metode ini berbeda dengan metode yang biasa digunakan oleh guru di MIM Jatisari tersebut. Metode ini lebih santai dan sesuai untuk siswa yang sulit memahami materi, serta dapat merangsang keingintahuan siswa dalam mendalami pengetahuan. Hal tersebut diharapkan mampu mengembalikan fokus siswa dalam belajar dan membuat siswa dapat memahami materi dengan mudah.
\end{abstract}

\section{Pendahuluan}

Pembelajaran merupakan proses komunikasi dua arah, mengajar dilakukan oleh pihak guru sebagai pendidik, sedangkan belajar dilakukan oleh pihak peserta didik atau siswa. Pembelajaran sebagai proses belajar yang dibangun oleh guru untuk mengembangkan kreativitas peserta didik yang dapat meningkatkan kemampuan berpikir peserta didik, serta dapat meningkatkan kemampuan mengonstruksi pengetahuan baru sebagai upaya meningkatkan penguasaan yang baik terhadap materi pembelajaran (Sagala, 2016).

Pembelajaran dimaksudkan untuk tercapainya tujuan tertentu agar pembelajaran berjalan efektif dan efisien. Belajar secara utuh dapat berarti proses pengarahan untuk pencapaian tujuan dan proses melakukan perbuatan melalui pengalaman yang diciptakan (Nurdyansyah, 2015). Proses pembelajaran dapat dipengaruhi oleh aktivitas, gaya, motivasi, dan minat belajar siswa. Faktor-faktor tersebut perlu mendapat perhatian dalam mendukung 
doi: 10.23917/bkkndik.v1i2.10765

efektivitas belajar. Peranan guru berpengaruh dalam proses pembelajaran melalui pemilihan model pembelajaran yang tepat dengan materi yang diajarkan karena suatu model belum tentu cocok digunakan untuk setiap pokok bahasan yang berbeda.

Model talking stick merupakan salah satu model yang melibatkan peserta didik dalam proses pembelajaran untuk berani mengungkapkan pendapat. Model ini dapat memberikan motivasi kepada peserta didik supaya aktif dalam memahami dan menemukan konsep sehingga peserta didik mampu menghubungkan soal dan teori yang ada.

Talking stick (tongkat berbicara) adalah metode pembelajaran dengan bantuan tongkat. Siapa yang memegang tongkat wajib menjawab pertanyaan dari guru setelah siswa mempelajari materi pokoknya. Selain itu, untuk melatih berbicara, model ini juga dapat menuntut siswa bekerja sama dengan temannya agar dapat mengerti dan siap untuk menjawab pertanyaan dari guru (Siregar, 2015).

Diharapkan dengan metode talking stick pada proses pembelajaran di MIM Jatisari, Desa Kedungdowo, Boyolali dapat meningkatkan hasil belajar siswa sesuai dengan upaya dan kemampuan mereka masing-masing. Dengan demikian, fungsi utama dari metode talking stick untuk tercapainya keberhasilan dalam menyampaikan materi pembelajaran.

Tujuan pengabdian ini adalah meningkatkan keaktifan dan pemahaman siswa dalam materi pembelajaran di sekolah. Dengan demikian, dapat mengetahui sejauh mana pengetahuan dan keaktifan siswa di kelas sehingga materi yang disampaikan dapat diterima dengan baik.

\section{Metode Pelaksanaan}

Metode pelaksanaan yang dipilih adalah pengamatan. Dari 30 anak ada 15 anak yang dijadikan sampel. Siswa diacak. Jadi, sampel ini tidak diidentifikasi berdasarkan tingkat kepandaian mereka. Selama 15 hari mereka mengikuti pembelajaran dengan metode talking stick. Pilihan metode itu didasarkan pengakuan banyak guru bahwa siswa mereka banyak yang pasif. Pertanyaan-pertanyaan yang dilontarkan oleh guru direspon dengan banyak diam. Guru tidak dapat mengetahui tingkat pemahaman mereka, kecuali misalnya dilanjutkan dengan jawaban tertulis. Bila respon tersebut berlangsung lama, maka dinamis akibat respon diam tersebut. Pembelajaran akan terasa lama dan membosankan. Oleh karena itu, tugas tambahan mengajar dalam kegiatan KKN-dik diterima oleh mahasiswa untuk digunakan memperkenalkan metode tersebut kepada siswa. Selama 15 hari perkembangan ke-15 siswa dipantau. Pada awalnya dibangun komunikasi agar siswa dapat nyaman bertahan di kelas. Membangun komunikasi amat penting karena kegiatan itu berlangsung lama dan mahasiswa tidak menginginkan terjadi penurunan jumlah peserta. Dengan berprinsip pada asuh-asih-asah anak menyukai kegiatan penbelajaran yang ditawarkan mahasiswa KKNDik. Teknik analisis yang digunakan yaitu analisis SWOT, yakni dengan memanfaatkan hasil observasi ketika melakukan PBM di kelas sebelum program kerja. Teknik analisis SWOT memiliki 4 kegiatan utama, yaitu: strengths, weaknesses, opportunities, dan threats. Langkah pertama yaitu mengevaluasi kekuatan, kedua menganalisis kelemahan, ketiga menganalisis kesempatan, dan terakhir menganalisis ancaman. Tujuan dari analisis SWOT yaitu 
untuk mendapatkan suatu solusi yang tepat terhadap suatu permasalahan.

\section{Hasil Pelaksanaan dan Pembahasan}

Dalam upaya meningkat hasil belajar siswa di era millennial yang di dalamnya siswa lebih berminat belajar dengan hal-hal yang menarik dan santai. Oleh karena itu, pembelajaran yang ditawarkan adalah pembelajaran dengan metode talking stick untuk siswa di MIM Jatisari, Kedungdowo, Boyolali. Metode pembelajaran ini dapat meningkatkan hasil belajar dan keaktifan siswa. Beberapa upaya untuk mendukung kegiatan ini adalah dengan metode SWOT tadi.

Pertama, yaitu Strength (Kekuatan), pembelajaran metode talking stick yang dilaksanakan di MIM Jatisari, Desa Kedungdowo, Boyolali bertujuan untuk meningkatkan keaktifan dan pemahaman siswa dalam materi pembelajaran di sekolah. Pada proses belajar-mengajar digunakan metode talking stick. Hal ini menuntut mereka untuk dapat aktif dalam pembelajaran sehingga pemahaman materi yang disampaikan akan meningkat.

Berdasarkan hal tersebut, metode pembelajaran ini secara umum bertujuan.

1. meningkatkan keaktifan dan minat belajar;

2. meningkatkan hasil belajar siswa; dan

3. merupakan upaya untuk membentuk sikap dan perilaku di dalam kelas.

Dengan demikian, pencapaian tujuan belajar tersebut adalah sebuah usaha untuk menghasilkan:

1. Kepribadian atau sikap dalam hal pengetahuan, keilmuan, dan konsep-konsep yang bersifat kognitif;

2. Hal personal bersifat afektif;
3. Perilaku dan keterampilan yang bersifat psikomotorik.

Ketiga hal tersebut sangat diperlukan dalam proses belajar-mengajar. Hal ini direncanakan sesuai dengan konteks materi agar menjadi satu kesatuan yang utuh. Dengan demikian, proses pembelajaran akan berjalan dengan baik sehingga didapatkan hasil belajar yang memuaskan.

Kegiatan pembelajaran dengan talking stick ini berlangsung kurang lebih selama satu bulan. Sebelumnya, (Supriyono, et al, 2018) telah menerapkan metode pembelajaran interaktif berbasis aplikasi mobile. Berawal dari situlah metode talking stick terkonsep.

Selama kegiatan berlangsung antusiasme siswa dalam belajar semakin terlihat. Misalnya, siswa lebih semangat dan senang ketika mengikuti pembelajaran. Sebelumnya, siswa sering malas ketika pembelajaran dimulai. Metode yang dipakai ternyata belum menggunakan metode yang membuat siswa aktif, inovatif, kreatif, efektif, dan menyenangkan. Guru nyaman dengan pembelajaran yang sudah bertahun-tahun diterapkannya.

Selain itu, sebelum pembelajaran dimulai, ada keinginan siswa agar guru melanjutkan metode talking stick tersebut. Melihat semangat serta antusiasme siswa tersebut, Tim KKN-Dik FKIP-UMS MIM Jatisari, Kedungdowo berusaha secara maksimal dalam memberikan pembelajaran dengan metode tersebut. Amat disadari oleh Kepala Sekolah bahwa dalam kegiatan KKNdik mahasiswa tidak berkonsentrasi dalam PBM, akan tetapi mahasiswa diminta untuk memberi warna pembelajaran dengan memperkenalkan metode dengan tujuan untuk 
peningkatan meningkatkan kegairahan dalam menerima pelajaran, apalagi mereka dipandang sosok yang memperkenalkan inovasi di ranah pendidikan. Mereka seusia kakak-kakak mereka.

Kedua, yaitu weaknesse (kelemahan) berdasarkan karakteristik anak usia sekolah dasar yang masih rentan untuk fokus dalam belajar membuat proses pembelajaran menggunakan metode talking stick menjadi sulit dikendalikan. Selain itu, siswa menjadi kurang kondusif karena takut mendapatkan stick dan diberi pertanyaan kemudian diminta untuk menjawabnya. Hal tersebut membuat kerja ekstra tim KKN-Dik FKIP-UMS dalam menggunakan metode tersebut, apalagi sudah sekian tahun siswa diperankan pasif oleh guru. Untuk pelaksanaan PBM dengan metode tersebut guru pun harus aktif. Tidak saja mereka bermodalkan pertanyaan, tetapi pertanyaan tersebut dapat mewakili materi yang diajarkan sehingga siswa mendapatkan pemahaman yang baik. Misalnya ialah mahasiswa yang menerapkan metode tersebut sudah mempersiapkan dan mengukur pertanyaan yang dilontarkan untuk siswa. Metode ini mengandung kelemahan, yakni siswa cenderung individu, materi yang kurang diserap, siswa yang pandai mudah menerima materi, dan guru sulit melakukan pengawasan (wordpress.com.). Jika demikian, perlu banyak sisi yang diperhatikan oleh calon guru untuk mengukur kekurangan dan kelebihan masingmasing metode. Merupakan tindakan yang sangat disarankan untuk memanfaatkan variasi teknik dan metode agar dihasilkan kualitas pemahaman anak didik yang utuh dan komprehensif.
Karena memiliki berbagai faktor yang membuat kurang fokusnya siswa dalam belajar, metode talking stick diimbangi dengan berbagai permainan dan membiarkan siswa untuk istirahat sejenak di sela-sela pembelajaran berlangsung. Hal ini diharapkan dapat mengembalikan fokus dan menambah minat belajar siswa.

Ketiga, yaitu opportunities (kesempatan), pembelajaran dengan metode talking stick ini mengacu pada pengalaman di lapangan yang menunjukkan berbagai kesulitan, permasalahan, dan bahkan kegagalankegagalan yang dialami siswa dalam belajar di sekolah. Hal ini yang mengakibatkan rendahnya rasa ingin tahu serta pengetahuan yang siswa dapatkan. Dalam satu kelas di sekolah biasanya terdapat banyak karakteristik yang berbeda-beda dalam belajar. Misalnya siswa dengan sifat yang lebih suka mendengarkan dibandingkan dengan mempraktikkan atau sebaliknya atau bahkan terdapat siswa yang kurang percaya diri sehingga takut untuk mengungkapkan apa yang ingin mereka sampaikan. Kondisi siswa yang demikian dialami siswa dalam waktu lama, apalagi mereka sudah menduduki kelas V SD. Situasi demikian perlu untuk diagendakan kegiatan pelatihan tentang metode, strategi, dan teknik pembelajaran yang dapat menyegarkan kembali kegiatan PBM di sekolah-sekolah pedesaan. Banyak titipan pesan dari Kepala atau Wakasek untuk FKIP-UMS, yakni disediakan narasumber untuk pembelajaran inovatif dan contoh. Instrumen, dan rubrik penilaian berbasis hots.

Selain faktor mengenai karakteristik siswa, terdapat pula faktor-faktor yang lain, yaitu: 
1. Intelegensi, yaitu kemampuan dan kecakapan siswa menghadapi dan menyesuaikan diri denga situasi yang ada secara cepat dan efektif.

2. Perhatian, yaitu perhatian terhadap materi yang sedang dihadapi termasuk potensi yang sangat mendukung mutu proses belajar siswa. Tingkat keberhasilan siswa dalam belajar siswa tergantung pada sejauh mana konsentrasi siswa terhadap materi pelajaran.

3. Minat, yaitu kecenderungan yang tetap untuk memperhatikan berbagai aktivitas belajar yang diminati. Bila minat siswa terbangun, maka dapat memunculkan suatu partisipasi aktif yang disertai rasa senang sehingga akan memperoleh kepuasan dalam belajar.

4. Bakat, yaitu kemampuan aktual dalam belajar yang menurut Hilgard disebut "the capacity to learn". Potensi actualities ini akan tampak setelah siswa belajar dan berlatih. Potensi ini sangat berarti bagi peningkatan kualitas belajar siswa di sekolah.

5. Motivasi, yaitu motor penggerak utama (terutama motivasi intrinsik) bagi siswa, terutama terkait dengan tujuan yang ingin dicapai oleh setiap siswa yang belajar.

6. Kematangan, James Drever menyatakan bahwa kematangan merupakan "prepareadeiness to respond" yaitu suatu fase pertumbuhan dan perkembangan dimana anak telah memiliki readiness, baik fisik maupun psikisnya.

7. Kesiapan, kecakapan-kecakapan dalam belajar menentukan kemajuan dalam belajar yang "react" (kesiapan memberi respons) terhadap suatu materi yang disajikan.

8. Kelelahan, dalam hal belajar kelelahan fisik maupun psikis sangat berdampak negatif bagi proses pembelajaran siswa.

Beberapa faktor diatas lah yang memotivasi kami untuk menciptakan pembelajaran dengan menggunakan metode talking stick yang dapat menumbuhkan minat belajar siswa serta meningkatkan pengetahuan dan meningkatkan hasil belajar siswa di sekolah.

Keempat yaitu Treatment (Tindakan) dalam menumbuhkan minat belajar siswa dapat diperoleh dari pengaruh internal serta eksternal. Pengaruh internal meliputi pembelajaran yang siswa dapatkan dari keluarga terutama kedua orang tua memberikan pelajaran mencakup kapasitas kognitif, afektif maupun psikomotorik. Faktor eksternal meliputi pembelajaran yang siswa dapatkan dari lingkungan teman sebaya, lingkungan masyarakat serta di lingkungan sekolah.

Mengingat metode talking stick kurang dapat mengakomodasi mereka yang kurang pandai, maka penerapan ke depan perlu dikolaborasi dengan metode (-metode) lain agar semua siswa terwakili, yakni siapa pun semakin meningkat pengetahuan dan keterampilan mereka. Ada pengaruh terhadap keaktifan belajar siswa (Pour, et al., 2018). Setelah itu, hasil belajar pun menjadi membaik. Hal ini ditunjukkan dalam pembelajaran IPA (Sari, et al. 2017). Dalam pembelajaran IPS pun metode tersebut dapat meningkatkan prestasi belajar (Muslimah, 2017). Oleh Puspitawangi (2016) metode tersebut digabungkan dengan media audio untuk pembelajaran IPS. Hasil belajar mereka menjadi signifikan. 
Metode talking stick tidak selalu dipilih untuk penguji pemahaman materi ajar. Untuk menguji kesiapan mental anak, bisa saja diawali pengetahuan umum di sekitar sekolah yang bisa dijawab oleh keseluruhan siswa. Jika diterapkan ke materi ajar, guru bisa memulainya dengan kegiatan membaca di kelas dengan materi yang sudah disiapkan. Dari yang termudah hingga yang sulit. Tujuannya untuk menanamkan keberanian pada diri siswa. Guru yang kreatif akan terus melakukan eksplorasi dalam pembelajaran. Misalnya metode Talking Stick dipadukan dengan media Microsoft Power Point. Hasil pembelajaran yang didapat lebih baik jika dibandingkan dengan model Talking Stick biasa serta model konvensional ditinjau dari kemampuan numerik (Mustikasari, et al., 2017). Sebelumnya, Fajri, et al. menggabungkannya strategi Joyful Learning Pembelajaran inipun berpengaruh secara signifikan terhadap prestasi belajar IPS (Fajri, et al., 2016).

Metode Talking Stick di MIM Jatisari sebatas pada pengenalan. Tujuan utama adalah siswa mau mengomunikasikan pendapat mereka. Padahal yang lazim dilaksanakan adalah guru menyampaikan materi yang hendak dipelajari dan memberi kesempatan siswa untuk mempelajarinya. Mereka melakukan diskusi untuk membahas permasalahan dari materi tersebut. Selanjutnya, guru mengisntruksikan siswa untuk menutup lalu guru mengambil tongkat dan memberikannya seorang murid. Guru memberikan pertanyaan yang dijawab oleh siswa yang memegang tongkat tersebut. Setelah siswa mendapatkan kesempatan untuk menjawab pertanyaan lalu guru membuat simpulan. Terakhir, guru melakukan evaluasi. Siswa yang sudah lama pasif sulit untuk diajak diskusi. Apalagi mereka masih berada di jenjang SD.

Akhirnya, untuk kondisi MIM Jatisari yang lebih prospektif adalah pemakaian metode tersebut untuk keterampilan berkomunikasi. Melalui penelitian Kristanti (2018), siswa kelas 6 SD dapat meningkat dalam kecakapan berkomunikasi mereka, seperti dalam menyampaikan pertanyaan dan menjawabnya, menyampaikan pendapat, pembicaraan singkat, jelas, dan mudah dimengerti, suaranya terdengar jelas, berbicara dengan melihat lawan bicara.ekspresi wajah yang ramah, dan menggunakan gerakan tangan yang sesuai dengan kata-kata yang diucapkan. Hal-hal itulah yang amat perlu dilanjutkan untuk KKNDik di masa depan sebelum melakukan pembenahan yang lainnya.

\section{Simpulan}

Implementasi pembelajaran menggunakan metode talking stick untuk meningkatkan keaktifan dan pemahaman siswa dalam pembelajaran di MIM Jatisari, Kedungdowo, Andong, Boyolali. Metode ini cukup memberikan nilai positif bagi siswa-siswi di sana. Dengan metode talking stick ini siswa dapat menambah wawasan dan pengetahuan yang belum atau sudah mereka dapatkan sebelumnya. Selain itu, metode talking stick juga menjadi salah satu usaha untuk meningkatkan minat belajar siswa dengan kegiatan-kegiatan yang menarik dan tidak membosankan untuk mereka.

Dengan metode talking stick ini dapat disimpulkan bahwa kegiatan belajar-mengajar dapat berlangsung secara efisien jika pengajar atau pembimbing mampu menciptakan suasana yang menyenangkan dan menarik perhatian 
siswa. Hal tersebut diharapkan mampu mengembalikan fokus siswa dalam belajar dan membuat siswa dapat memahami materi dengan mudah.

\section{Daftar Pustaka}

Fajri, Nurul, Anwar Yoesoef, Muhammad Nur. 2016. "Pengaruh Model Pembelajaran Kooperatif Tipe Talking Stick dengan Strategi Joyful Learning terhadap Prestasi Belajar Siswa pada Mata Pelajaran IPS Kelas VII MTSN Meuraxa Banda Aceh". Jurnal Ilmiah Mahasiswa Pendidikan Sejarah, 1(1): 98-109.

Kristanti, hana Septiana. (2018) "Peningkatan Kecakapan Berkomunikasi Kelas 6 dengan Talking Stick Berbantuan Salindia". Scolaria: Jurnal Pendidikan dan Kebudayaan, 8(3): 293-301

Muslimah, Umi. (2017). "Peningkatan Prestasi Belajar IPS melalui Implementasi Active Learning Tipe Talking Stick. Basic Education, 6(12): 1.175-1.182. http://journal.student.uny.ac.id/ojs/inde x.php/pgsd/article/view/10366

Mustikasari, Mariska, Isnani, Purwo Susongko. 2017. "Keefektifan Model Pembelajaran Talking Stick Berbantu Media Microsoft Power Point terhadap Prestasi Belajar Matematika Ditinjau dari Kemampuan Numerik Materi Pokok Statistika". JurnalPendidikan MIPA Pancasakti, 1(1): 65-71.http://ejournal.ups.ac.id/index.php/jpmp
Nurdyansyah, N.,\& Widodo, A. (2015). Inovasi Teknologi Pembelajaran. Sidoarjo: Nizamia Learning Center.

Pour, Agustina Novitasari, Lovy Herayanti, Baiq Azmi Sukroyanti. 2018. Pengaruh Model Pembelajaran Talking Stick terhadap Keaktifan Belajar Siswa". Jurnal Penelitian dan Pengkajian Ilmu Pendidikan: e-Saintika, 2(1): 36-40.

Puspitawangi, Kadek Rai, I Made Citra Wibawa, Ketut Pudjawan. (2016). “ Pengaruh Model Pembelajaran Kooperatif Tipe Talking Stick Berbantuan Media Audio terhadap Hasil Belajar IPS Siswa". E-Journal PGSD Universitas Pendidikan Ganesha Jurusan PGSD, 4(1): 1-12. https://ejournal.undiksha.ac.id

Sagala. S. (2016). Konsep dan Makna Pembelajaran. Bandung: Alfabeta.

Sari, Swastika, Astuti Wijayanti. 2017."Talking Stick: Hasil Belajar IPA dan Kemampuan Kerja Sama Siswa". Wacana Akademika, $1(2)$.

Siregar, S. (2015). "Pengaruh Model Pembelajaran Talking Stick terhadap Hasil Belajar dan Aktivitas Siswa pada Konsep Sistem Indera". Jurnal Biotik, 3(2): 100-106. https://jurnal.arraniry.ac.id

Supriyono, H., Adhantoro, M. S., \& Rahmadzani, R. F. (2018). Developing Mobile Interactive Learning Media with Educational Game for Supporting Javanese Letters Learning. Advanced Science Letters, 24(12), 9173-9177. 